\title{
Combining ability and mode of gene action in cassava for resistance to cassava green mite and cassava mealy bug in Malawi
}

\author{
Michael Malandula Chipeta $^{1 *}$, James M. Bokosi ${ }^{1}$, Vincent W. Saka ${ }^{1}$ and Ibrahim R. M. Benesi ${ }^{2}$ \\ ${ }^{1}$ Department of Crops and Soil Sciences, Bunda College of Agriculture, P.O. Box 219, Lilongwe, Malawi. \\ ${ }^{2}$ Chitedze Agricultural Research Station, P.O. Box 158, Lilongwe, Malawi.
}

Accepted 12 August, 2013

\begin{abstract}
The need to develop new improved varieties resistant to cassava green mite (CGM) and cassava mealy bug (CMB) as well as high yielding varieties requires knowledge on the mode of gene action controlling the expression of resistant traits to these pests. Therefore, a study was carried out to determine combining abilities and mode of gene action for resistance to CGM and CMB by crossing cassava genotypes in a $7 \times 7$ diallel mating design. The $F_{1}$ progenies were evaluated in a seedling trial laid in randomised complete block design (RCBD) with two replicates. Results indicated highly significant $(P<0.001)$ general combining ability $(G C A)$ and specific combining ability (SCA) mean squares for CGM, CMB, average root number per plant and fresh root weight (kg per plant) which signified preponderance of significant variability existing in breeding material attributable to additive and nonadditive gene effects. GCA variances for all the traits studied were lower than SCA variances which suggested that non-additive gene action was more important than additive gene action in influencing the traits. Mulola was the overall best general combiner for all the traits, followed by TMS4 (2)1425 and 01/1316. The best ranking hybrids were Mulola $\times$ 01/1313, Silira $\times$ TMS4(2)1425, Depwete $\times$ Silira, Mulola $\times$ Silira, Depwete $\times$ Maunjiri and 01/1316 $\times$ TMS4(2)1425. Overall, the results suggested that when designing breeding programs breeders should exploit both additive and non additive types of gene action.
\end{abstract}

Key words: Cassava green mite, cassava mealy bug, general combining ability, gene action, specific combining ability.

\section{INTRODUCTION}

Cassava (Manihot esculenta Crantz) is a primary staple food crop for more than 800 million people in the world (Lebot, 2009), particularly in the developing countries where it is an essential energy source for many resource constrained people who face problems of food availability (Opeke, 1991; Axtell and Adams, 1993). In Malawi, it is a staple food crop for almost 30 to $40 \%$ of the population in addition to providing income (Moyo et al., 1998). It is a multi-purpose root crop containing 25 to $35 \%$ starch; leaves are used as vegetables (containing significant amount of protein, iron and other nutrients) (Hahn, 1988; FAO, 1993; Moyo et al., 1998; Nweke et al., 2002); pellets from cassava are used in manufacturing animal feed; its starch is used as sweeteners, thickeners (in food industries) and also used in the textile paper industry (Silvestre, 1989; Githunguri, 1991).

Despite its importance in the farming communities, its production is constrained by a number of factors which 
include insect infestation (Bellotti, 2002). Since cassava is grown among many crops in traditional farming systems, pest control is often a low priority and under such conditions, yields are often low, with a large gap between potential yields and that realised by producers. Among the arthropod pests reportedly causing crop losses in Africa, are cassava green mite (CGM) and cassava mealy bug (CMB) (IITA, 1990; Bellotti, 2002).

Several experimental trials have revealed significant fresh root yields reductions due to infestation, for instance, $15 \%$ yield reductions in resistant cultivars and $73 \%$ loss in susceptible cultivars have been attributed to CGM attack (Bellotti, 2002). Yield loss due to CMB on susceptible cultivars can reach as high as $88 \%$ (Bellotti et al., 1987). Bellotti (2002) reported an average yield reduction due to arthropod infestation to be around 9.0 tonnes ha $^{-1}$ in Africa against a potential yield of 21.3 tons $\mathrm{ha}^{-1}$. Since the continual use of pesticides is not feasible for low income small scale farmers, coupled with adverse effects on the natural enemies, host plant resistance has been advocated for the control of pests in order to reduce their populations below economic injury levels (Bellotti, 2002). However, there is limited knowledge on the inheritance of resistant traits in cassava (CIAT, 2004).

In Malawi, virtually no genetic studies on cassava have been done to determine the mode of gene action controlling the expression of CGM and CMB resistant traits. Knowledge of inheritance pattern of various traits would aid in selection of superior genotypes and designing efficient cassava breeding programs aimed at incorporating economically important traits that would ensure sustained productivity and production by smallholder farmers in Malawi. The objective of this study was to determine combining abilities and mode of gene action controlling the expression of CGM and CMB traits in cassava in order to select superior genotypes and design an efficient cassava breeding programme for developing cassava varieties resistant to both CGM and $\mathrm{CMB}$ as well as high yielding varieties.

\section{MATERIALS AND METHODS}

\section{Plant materials}

A crossing block was established at Chitedze Research Station in 2009 where seven parents (Mulola, 01/1313, Depwete, 01/1316, Silira, TMS4 (2)1425 and Maunjiri) were crossed in a diallel mating design based on the Griffing's (1956) method three. The parents constituted locally bred varieties and introductions from the International Institute of Tropical Agriculture, with different characteristics including taste (sweet and bitter), root yield, root quality and reaction to insect pests (green mite and mealy bug) and diseases (cassava mosaic disease, cassava brown streak disease). The choice of parents for the current experiment was mainly based on the ability to produce a reasonable amount of seed for each of the required $F_{1}$ crosses in a complete and balanced diallel design. Crossing was done in March 2010 using hand pollinated method. A total of $21 F_{1}$ crosses and 21 reciprocals derived from a $7 \times 7$ diallel mating design were the genetic material used in the study.

\section{Seedling nursery}

Seeds were germinated and grown on $9^{\text {th }}$ November 2010 in a greenhouse in floating trays according to families at Chitedze Agricultural Research Station. Watering was done twice a day to ensure good germination and development. Two months after sowing, the seedlings were transplanted on $13^{\text {th }}$ January, 2011 for field evaluation in a seedling trial at Chitedze Agricultural Research Station farm, Lilongwe.

\section{Seedling field trial}

Chitedze Agricultural Research Station is located $16 \mathrm{~km}$ west of the Capital City, Lilongwe, on the Lilongwe-Mchinji road leading to Zambia ( $\left.13^{\circ} 85^{\prime} \mathrm{S} 33^{\circ} 38^{\prime} \mathrm{E}\right)$. It lies on an altitude of $1146 \mathrm{~m}$ above sea level. The Chitedze Agricultural Research Station farm, at which the $F_{1}$ seedling trial was conducted, receives rains between November and March. The soils are Sandy clay loam with the $\mathrm{pH}$ range of 5.2 to 5.8. Data of temperature and rainfall during experimentation period (November, 2010 to December, 2011) are presented in Figure 1.

The seedlings were planted at a spacing of $90 \mathrm{~cm} \times 50 \mathrm{~cm}$. Parents (Mature stems $25 \mathrm{~cm}$ long) were also planted at the same spacing but 20 plants per genotype/variety of each parent. No irrigation and fertiliser were applied at this stage. The seedlings were evaluated using a randomised complete block design with two replicates. Individual plants in each cross and seven parental stands were assessed for their reaction to CGM and CMB due to natural infestation at 3, 6, 9 and 12 months after planting (MAP). The assessment was based on the standard 5 point scoring scale for CGM and CMB, where a score of 1 indicates no obvious symptom and a score of 5 indicates severe symptoms (IITA, 1990). At harvest, $12 \mathrm{MAP}$, the individual plants were assessed for their number of storage roots per plant and fresh root weight (kg per plant).

\section{Data analysis}

Preliminary analysis of the data showed that CGM and CMB severities were highest at 6 MAP and 12 MAP respectively and the variance of the mean differences were also the highest. Subsequently, analysis of variances of the crosses and parents and their combining abilities were therefore, based on CGM severity at 6 MAP and CMB severity at 12 MAP, which gives an overall impression of the symptom severity potential of a genotype. Data was analysed for combining ability variances, estimates of genetic parameters and heritability, and phenotypic correlations using Agrobase (2000) and Microsoft excel 2007. CMB severity indices were transformed [square root $(x+3 / 8)$ ] before performing the analysis (reported using original values after back-transformation). The Pearson's phenotypic correlation coefficients were also calculated for the following four traits: average root number per plant, fresh root weight (kg per plant), CGM and CMB. The parental genotypes were considered as a fixed population; therefore results only concern this set of heterozygous genotypes and deductions from this study may not be generalized.

\section{RESULTS}

\section{Estimation of combining ability variances}

General combining ability (GCA), specific combining ability (SCA), and reciprocal mean square values were 
Total Monthly Rainfall $(\mathrm{mm})$ and Mean Temperature $\left({ }^{\circ} \mathrm{C}\right)$

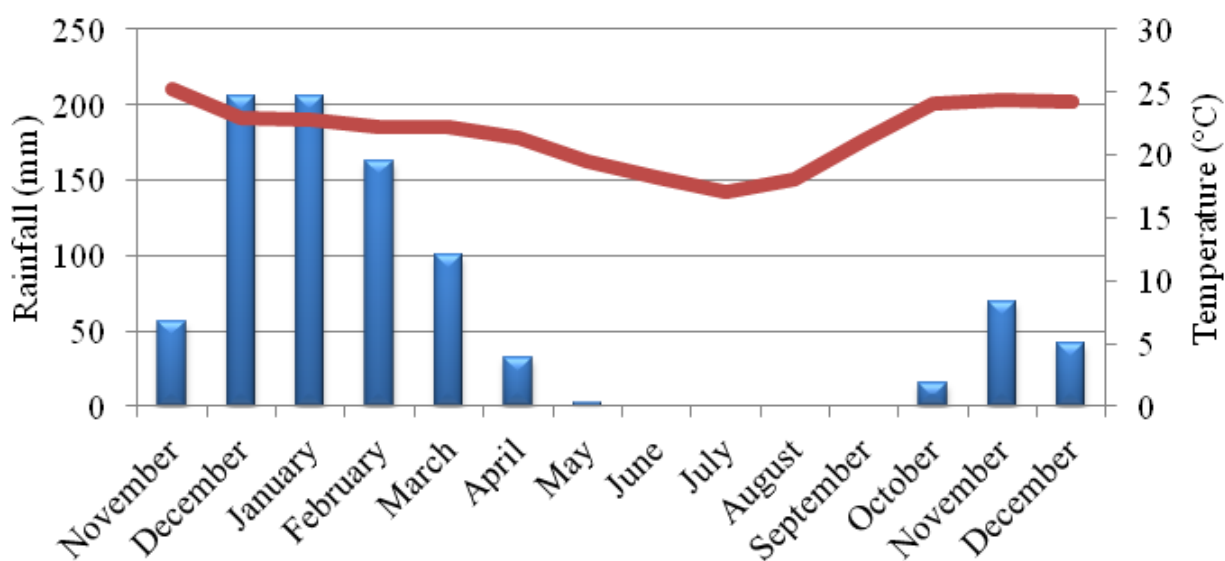

Experimentation period (November, 2010-December, 2011)

Total Rainfall (mm) $\rightleftharpoons$ Mean Temperature $(0 \mathrm{C})$

Figure 1. Monthly rainfall $(\mathrm{mm})$ and mean temperature $\left({ }^{\circ} \mathrm{C}\right)$ during seedling trial experimentation period (November, 2010-December, 2011).

Table 1. Mean square values and estimates of genetic components for cassava green mite, cassava mealy bug, average root number and fresh root weight (kg per plant).

\begin{tabular}{|c|c|c|c|c|c|}
\hline Source & DF & CGM & CMB & ARN & FRW \\
\hline Genotype & 41 & $0.484^{\star \star \star}$ & $0.077^{\star \star \star}$ & $3.044^{* * *}$ & $0.337^{\star \star \star}$ \\
\hline GCA & 6 & $0.329^{\star \star \star}$ & $0.037^{\star \star *}$ & $3.513^{\star \star *}$ & $0.239^{\star \star \star}$ \\
\hline SCA & 14 & $0.169^{\star * \star}$ & $0.050^{* * *}$ & $1.538^{* \star *}$ & $0.240^{* * *}$ \\
\hline Reciprocal & 21 & $0.269^{\star \star \star}$ & $0.031^{* \star *}$ & $0.942^{* \star *}$ & $0.101^{* * *}$ \\
\hline Error & 41 & 0.008 & 0.007 & 0.239 & 0.018 \\
\hline$\delta^{2} g c a$ & & 0.0006 & 0.0006 & 0.0205 & 0.0015 \\
\hline$\delta^{2} \mathrm{sca}$ & & 0.0025 & 0.0023 & 0.0796 & 0.0059 \\
\hline$\delta^{2} A$ & & 0.0012 & 0.0012 & 0.0410 & 0.0030 \\
\hline$\delta^{2} D$ & & 0.0025 & 0.0023 & 0.0796 & 0.0059 \\
\hline PR & & 0.32 & 0.34 & 0.34 & 0.34 \\
\hline$\left(\sigma^{2} D / \sigma^{2} A\right)^{1 / 2}$ & & 1.44 & 1.38 & 1.39 & 1.40 \\
\hline $\mathrm{H}^{2}(\%)$ & & 56.60 & 57.10 & 57.40 & 57.10 \\
\hline$h^{2}(\%)$ & & 18.00 & 19.60 & 19.50 & 19.20 \\
\hline
\end{tabular}

$\mathrm{CGM}=$ cassava green mite, $\mathrm{CMB}=$ cassava mealy bug, $\mathrm{ARN}=$ average root number per plant, $\mathrm{FRW}=$ fresh root weight ( $\mathrm{kg}$ per plant), $\mathrm{DF}=$ Degrees of freedom, $\mathrm{GCA}=$ general combining ability, $\mathrm{SCA}=$ specific combining ability, $\mathrm{PR}=$ Prediction ratio, $\mathrm{H}^{2}=$ broad sense heritability, $\mathrm{h}^{2}=$ narrow sense heritability, ${ }^{* * *} \mathrm{P}<0.001$.

highly significant $(\mathrm{P}<0.001)$ for all the traits $(\mathrm{CGM}, \mathrm{CMB}$, average root number per plant and fresh root weight $(\mathrm{kg}$ per plant) (Table 1).

\section{General combining ability effects}

The GCA effects for all the traits are presented in Table 2. The best significant $(P<0.001)$ GCA effect for CGM was observed on Mulola (-0.24) followed by 01/1316 ($0.10)$ and TMS4 (2)1425 (-0.10), and the worst positive GCA value was observed on 01/1313 (0.29).For CMB, two parents, namely Silira (-0.09) and Mulola $(-0.08)$ had significant $(P<0.001)$ negative $G C A$ values and were the best general combiners for this trait, and the worst combiner for this trait was Depwete (0.07). GCA effects for average root number per plant showed positive significant $(\mathrm{P}<0.001)$ values for Mulola $(0.76)$ and $01 / 1316$ 
Table 2. Mean and GCA effects of genotypes for cassava green mite, cassava mealy bug, average root number per plant and fresh root weight ( $\mathrm{kg}$ per plant).

\begin{tabular}{|c|c|c|c|c|c|c|c|c|}
\hline \multirow{2}{*}{$\begin{array}{l}\text { Parental } \\
\text { Genotype }\end{array}$} & \multicolumn{2}{|c|}{ CGM } & \multicolumn{2}{|c|}{ CMB } & \multicolumn{2}{|c|}{ ARN } & \multicolumn{2}{|c|}{ FRW } \\
\hline & Mean & GCA & Mean & GCA & Mean & GCA & Mean & GCA \\
\hline Mulola & 4.00 & $-0.24^{\star \star *}$ & 2.65 & $-0.08^{\star \star \star}$ & 4.12 & $0.76^{\star * *}$ & 1.39 & $0.30^{\star * *}$ \\
\hline $01 / 1313$ & 3.92 & $0.29^{* * *}$ & 1.26 & -0.01 & 4.09 & $-0.42^{\star *}$ & 0.98 & $-0.09^{*}$ \\
\hline Depwete & 3.71 & $0.12^{\star * *}$ & 2.22 & $0.07^{\star *}$ & 4.10 & $-0.69^{\star \star *}$ & 1.21 & $0.09^{*}$ \\
\hline $01 / 1316$ & 4.53 & $-0.10^{* *}$ & 1.24 & 0.04 & 2.99 & $0.73^{\star \star \star}$ & 0.83 & 0.01 \\
\hline Silira & 4.00 & $0.12^{\star \star \star}$ & 1.82 & $-0.09^{* * *}$ & 3.23 & $-0.47^{\star *}$ & 0.88 & $-0.17^{\star * *}$ \\
\hline TMS4(2)1425 & 3.29 & $-0.10^{\star *}$ & 1.00 & 0.04 & 2.34 & 0.28 & 0.68 & $-0.09^{*}$ \\
\hline Maunjiri & 3.43 & $-0.09^{\star *}$ & 1.00 & 0.02 & 4.05 & -0.19 & 1.01 & -0.06 \\
\hline $\operatorname{LSD}(0.05)$ & 0.03 & & 0.18 & & 0.61 & & 0.05 & \\
\hline SE (Gi) & & 0.03 & & 0.02 & & 0.14 & & 0.04 \\
\hline $\mathrm{SE}(\mathrm{Gi}-\mathrm{Gj})$ & & 0.04 & & 0.04 & & 0.22 & & 0.09 \\
\hline
\end{tabular}

$\mathrm{CGM}=$ cassava green mite, $\mathrm{CMB}=$ cassava mealy bug, $\mathrm{ARN}=$ average root number per plant, $\mathrm{FRW}=$ fresh root weight $(\mathrm{kg}$ per plant), SE (Gi) = standard error for any GCA effect; SE (Gi -Gj) =standard error of the difference between any two effects, ${ }^{\star} \mathrm{P}<0.05,{ }^{\star \star} \mathrm{P}<0.01,{ }^{* \star *} \mathrm{P}<0.001$.

(0.73) while Depwete $(-0.69)$ was the overall worst combiner for this trait with a significant negative value.In terms of fresh root weight (kg per plant), Mulola was the best general combiner which had a significant $(\mathrm{P}<0.001)$ positive value $(0.30)$ followed by Depwete $(0.09)$. Silira was the worst combiner with a significant negative GCA value of -0.17 .

\section{Specific combining ability effects}

Specific combining ability effects for the $F_{1}$ crosses and their reciprocals are presented in Tables 3 and 4. Based on significantly lower mean performance and SCA effects, only five crosses were most desirable for CGM, and these were Mulola $\times$ Silira, Mulola $\times 01 / 1313$, Depwete $\times$ 01/1316, Silira $\times$ TMS4(2)1425 and TMS4(2)1425 × Maunjiri. Nine hybrids exhibited desirable significantly negative SCA effects for CMB and nine as well recorded significantly positive SCA effects, while the rest had non-significant SCA effects. The largest desirable SCA effects were manifested in the two reciprocals Maunjiri $\times$ Silira $(-0.28)$ and Maunjiri $\times$ TMS4 (2) $1425(-0.21)$. The most undesirable significant SCA effect was on Mulola $\times$ Depwete (0.31).

Hybrids SCA effects and their mean performance for average root number per plant revealed that Mulola $\times$ 01/1313, 01/1316 × TMS4 (2)1425, Depwete $\times$ Maunjiri, Depwete $\times$ Silira and Silira $\times$ TMS4 (2) 1425 were the most promising hybrids as their mean performance and SCA effects were highly significant.

Eighteen of 42 crosses exhibited significant SCA effects for fresh root weight (kg per plant) of which, six $F_{1}$ crosses and three reciprocals had desirable positive SCA effects and in undesirable negative direction for nine crosses. Twenty four hybrids showed non-significant SCA values.

\section{Gene action and relative importance of general and specific combining abilities}

The general combining ability variances $\left(\delta^{2} \mathrm{gca}\right)$ for all the traits in this study were lower than specific combining ability variances $\left(\delta^{2} s c a\right)$ (Table 1$)$. The additive to total genetic variance ratio [The prediction ratio, $\mathrm{PR}=2 \delta^{2} \mathrm{gca} /$ $\left(2 \delta^{2}\right.$ gca $+\delta^{2}$ sca) ] for all the traits was less than 1 while the average degree of dominance $\left[\left(\sigma^{2} D / \sigma^{2} A\right)^{1 / 2}\right]$ for all the traits was greater than unit. Broad sense heritability ranged from $56.6 \%$ to $57.4 \%$ and narrow sense heritability $(18.0 \%$ to $19.6 \%)$ for all the traits.

\section{Estimates of phenotypic correlation for cassava green mite, cassava mealy bug, average root number per plant and fresh root weight (kg per plant)}

Correlation coefficients (Table 5) indicated a highly significant positive correlation between root number per plant and fresh root weight ( $\mathrm{kg}$ per plant) $(\mathrm{r}=0.42, \mathrm{p}<$ 0.001 ) and highly significant negative correlation between CGM and fresh root weight ( $\mathrm{kg}$ per plant) $(\mathrm{r}=-0.53, \mathrm{p}<$ $0.001)$. In addition, there was a significant negative correlation between CGM and average root number ( $r=-$ $0.25, \mathrm{p}<0.05)$.

\section{DISCUSSION}

\section{Estimation of combining ability variances}

Significant GCA and SCA mean square values for all the traits signified preponderance of significant variability existing in breeding material attributable to both additive and non-additive gene effects. These results are consistent with Kamau et al. (2010) and Parkes (2011) 
Table 3. Mean and SCA effects of the $F_{1}$ crosses for cassava green mite, cassava mealy bug, average root number per plant and fresh root weight ( $\mathrm{kg}$ per plant).

\begin{tabular}{|c|c|c|c|c|c|c|c|c|}
\hline \multirow{2}{*}{$F_{1}$ Crosses } & \multicolumn{2}{|c|}{ CGM } & \multicolumn{2}{|c|}{ CMB } & \multicolumn{2}{|c|}{ ARN } & \multicolumn{2}{|c|}{ FRW } \\
\hline & Mean & SCA & Mean & SCA & Mean & SCA & Mean & SCA \\
\hline Mulola $\times 01 / 1313$ & 3.13 & $-0.43^{* \star *}$ & 1.10 & -0.06 & 6.06 & $1.17^{\star \star \star *}$ & 1.91 & $0.61^{* * *}$ \\
\hline Mulola $\times$ Depwete & 4.39 & $0.29^{\star \star \star}$ & 3.20 & $0.31^{\star \star \star}$ & 3.75 & -0.16 & 1.13 & $-0.20^{\star}$ \\
\hline Mulola $\times 01 / 1316$ & 4.12 & 0.03 & 1.18 & -0.06 & 5.88 & 0.38 & 1.28 & $0.25^{\star \star}$ \\
\hline Mulola $\times$ Silira & 2.88 & $-0.26^{* * *}$ & 1.42 & 0.06 & 5.18 & 0.34 & 2.13 & $0.36^{\star \star *}$ \\
\hline Mulola $\times$ TMS4(2)1425 & 4.42 & $0.53^{* * *}$ & 1.00 & $-0.15^{* *}$ & 4.90 & -0.50 & 0.93 & $-0.53^{* * *}$ \\
\hline Mulola $\times$ Maunjiri & 3.87 & $-0.16^{* *}$ & 1.13 & $-0.10^{*}$ & 3.67 & $-1.22^{\star \star \star}$ & 0.93 & $-0.50^{\star \star \star}$ \\
\hline 01/1313 $\times$ Depwete & 4.38 & 0.01 & 1.23 & $-0.18^{* * *}$ & 2.30 & $-0.98^{\star \star}$ & 1.24 & 0.09 \\
\hline $01 / 1313 \times 01 / 1316$ & 4.16 & $0.17^{\star *}$ & 2.70 & $0.18^{\star \star *}$ & 4.63 & $-0.65^{\star}$ & 0.95 & $-0.36^{\star \star \star}$ \\
\hline $01 / 1313 \times$ Silira & 4.54 & $0.26^{\star \star \star}$ & 1.09 & -0.05 & 2.39 & -0.42 & 0.74 & $-0.31^{\star \star \star}$ \\
\hline 01/1313×TMS4(2)1425 & 4.43 & -0.08 & 1.85 & $0.10^{*}$ & 2.90 & -0.52 & 0.86 & -0.07 \\
\hline $01 / 1313 \times$ Maunjiri & 4.50 & 0.07 & 1.60 & 0.00 & 3.71 & $1.40^{* * *}$ & 1.14 & 0.03 \\
\hline Depwete $\times 01 / 1316$ & 3.71 & $-0.27^{\star \star \star}$ & 2.55 & 0.07 & 3.865 & -0.52 & 1.50 & 0.11 \\
\hline Depwete $\times$ Silira & 4.05 & -0.04 & 1.38 & $-0.10^{*}$ & 4.90 & $0.61^{*}$ & 1.31 & -0.09 \\
\hline Depwete $\times$ TMS4(2)1425 & 3.64 & $0.16^{\star \star}$ & 1.64 & $0.10^{*}$ & 3.67 & 0.33 & 1.33 & 0.05 \\
\hline Depwete $\times$ Maunjiri & 4.59 & $-0.15^{\star \star}$ & 1.40 & $-0.20^{\star \star \star}$ & 4.40 & $0.73^{*}$ & 1.30 & 0.04 \\
\hline $01 / 1316 \times$ Silira & 4.25 & 0.01 & 1.48 & -0.05 & 4.60 & -0.37 & 0.89 & -0.11 \\
\hline 01/1316× TMS4(2)1425 & 3.83 & $-0.11^{*}$ & 1.00 & $-0.15^{* *}$ & 5.50 & $0.62^{*}$ & 1.15 & -0.09 \\
\hline $01 / 1316 \times$ Maunjiri & 4.64 & $0.16^{\star \star}$ & 2.55 & 0.01 & 7.30 & 0.54 & 1.40 & $0.21^{*}$ \\
\hline Silira $\times$ TMS4(2) 1425 & 3.61 & $-0.29^{* * *}$ & 1.30 & -0.02 & 4.59 & $0.67^{\star}$ & 1.71 & $0.30^{\star * *}$ \\
\hline Silira $\times$ Maunjiri & 4.50 & $0.31^{* * *}$ & 1.00 & $0.16^{* *}$ & 2.50 & $-0.83^{\star \star}$ & 0.50 & -0.14 \\
\hline TMS4(2)1425×Maunjiri & 3.43 & $-0.23^{\star \star *}$ & 1.44 & $0.13^{*}$ & 3.55 & $-0.60^{*}$ & 1.36 & $0.34^{* * *}$ \\
\hline LSD (0.05) & 0.25 & & 0.24 & & 1.40 & & 0.38 & \\
\hline $\mathrm{SE}\left(\mathrm{S}_{\mathrm{ij}}\right)$ & & 0.05 & & 0.05 & & 0.28 & & 0.08 \\
\hline $\operatorname{SE}\left(S_{\mathrm{ij}}-S_{\mathrm{kl}}\right)$ & & 0.07 & & 0.06 & & 0.39 & & 0.10 \\
\hline
\end{tabular}

$\mathrm{CGM}=$ cassava green mite, $\mathrm{CMB}=$ cassava mealy bug, $\mathrm{ARN}=$ average root number per plant, $\mathrm{FRW}=$ fresh root weight (kg per plant), $\mathrm{SCA}=$ specific combining ability, $\mathrm{SE}=$ standard error, ${ }^{*} \mathrm{P}<0.05,{ }^{* *} \mathrm{P}<0.01,{ }^{* * *} \mathrm{P}<0.001$.

findings especially on root number per plant and fresh root weight ( $\mathrm{kg}$ per plant); and in sharp contrast with DaSilva (2008) in which GCA was not significant for average root number, fresh root weight and cassava mealy bug. The presence of significant reciprocal effects in the inheritance of these traits means that cytoplasmic effects were important in the genetic control of these traits.

\section{General combining ability effects}

Genotypes with negative significant GCA values for CGM and $\mathrm{CMB}$ could be desirable parents for developing hybrids as well as for inclusion in breeding program aimed at producing varieties resistant to CGM and CMB since negative values indicate contribution towards resistance (DaSilva, 2008; Owolade et al., 2008). This means that if such genotypes are included in the breeding program, they may contribute favourable alleles in the synthesis of new varieties resistant to CGM and CMB.
Genotypes with significant positive GCA values for average root number per plant and fresh root weight $(\mathrm{kg}$ per plant) were the superior genotypes which meant that they contributed the most to these traits, while those with significant negative values performed below average of this set of parents, hence undesirable. The overall best general combiner for all the traits therefore, meant that it could be used for the improvement of a number of traits in a breeding program. However, it was difficult to have a parent with best GCA effects in all the traits which meant that recombination is inevitable to incorporate important traits in a particular genotype.

\section{Specific combining ability effects}

The distribution of $F_{1}$ crosses and their reciprocals for the four traits in relation to GCA effects of parental combinations revealed that almost all types of SCA effects were derived from any type of GCA values and not necessarily from best general combiners. This implies that allelic and non-allelic interactions were involved in the 
Table 4. Mean and SCA effects of the reciprocal crosses for cassava green mite, cassava mealy bug, average root number per plant and fresh root weight (kg per plant).

\begin{tabular}{|c|c|c|c|c|c|c|c|c|}
\hline \multirow{2}{*}{ Reciprocal crosses } & \multicolumn{2}{|c|}{ CGM } & \multicolumn{2}{|c|}{ CMB } & \multicolumn{2}{|c|}{ ARN } & \multicolumn{2}{|c|}{ FRW } \\
\hline & Mean & SCA & Mean & SCA & Mean & SCA & Mean & SCA \\
\hline 01/1313 $\times$ Mulola & 4.13 & $-0.50^{\star \star *}$ & 1.11 & -0.002 & 5.78 & 0.14 & 2.30 & $-0.20^{*}$ \\
\hline Depwete $\times$ Mulola & 3.98 & $0.20^{* *}$ & 1.80 & $0.20^{\star *}$ & 4.88 & -0.57 & 1.80 & $-0.34^{* * *}$ \\
\hline Depwete $\times 01 / 1313$ & 4.39 & -0.05 & 1.11 & 0.02 & 2.33 & -0.02 & 1.50 & -0.13 \\
\hline 01/1316 $\times$ Mulola & 3.27 & $0.43^{* * *}$ & 1.30 & -0.02 & 6.68 & -0.40 & 2.40 & $-0.56^{\star \star *}$ \\
\hline $01 / 1316 \times 01 / 1313$ & 4.58 & $-0.21^{\star *}$ & 1.80 & 0.12 & 3.50 & 0.56 & 0.75 & 0.10 \\
\hline 01/1316 × Depwete & 3.81 & -0.05 & 1.60 & $0.15^{\star}$ & 4.00 & -0.07 & 1.48 & 0.01 \\
\hline Silira $\times$ Mulola & 4.39 & $-0.76^{\star \star *}$ & 1.00 & 0.08 & 4.89 & 0.14 & 1.41 & $0.36^{* * *}$ \\
\hline Silira $\times 01 / 1313$ & 4.83 & $-0.15^{\star}$ & 1.14 & -0.01 & 3.80 & $-0.71^{*}$ & 0.70 & 0.02 \\
\hline Silira $\times$ Depwete & 4.36 & $-0.16^{*}$ & 1.00 & 0.07 & 2.80 & $1.05^{\star *}$ & 0.90 & $0.21^{*}$ \\
\hline Silira × 01/1316 & 3.83 & $0.21^{* *}$ & 1.00 & 0.09 & 4.00 & 0.30 & 1.13 & -0.12 \\
\hline TMS4(2)1425× Mulola & 4.00 & $0.21^{* *}$ & 1.00 & 0.00 & 5.00 & -0.05 & 1.00 & -0.04 \\
\hline TMS4(2)1425×01/1313 & 3.83 & $0.30^{\star \star *}$ & 1.92 & -0.01 & 4.60 & $-0.85^{*}$ & 1.22 & 0.18 \\
\hline TMS4(2)1425×Depwete & 4.75 & $-0.56^{\star \star \star}$ & 2.65 & $-0.16^{*}$ & 5.00 & -0.67 & 1.33 & 0.00 \\
\hline TMS4(2)1425×01/1316 & 3.58 & 0.12 & 1.62 & -0.11 & 6.59 & -0.54 & 1.08 & 0.04 \\
\hline TMS4(2)1425 × Silira & 3.89 & $-0.14^{*}$ & 1.29 & 0.00 & 5.19 & -0.30 & 0.93 & $0.39^{* * *}$ \\
\hline Maunjiri × Mulola & 3.17 & $0.35^{\star \star *}$ & 1.00 & 0.03 & 3.85 & -0.09 & 1.13 & -0.10 \\
\hline Maunjiri × 01/1313 & 4.05 & $0.23^{* * *}$ & 1.47 & 0.02 & 6.68 & $-1.48^{* * *}$ & 1.20 & -0.03 \\
\hline Maunjiri $\times$ Depwete & 3.18 & $0.71^{\star \star \star}$ & 1.00 & 0.08 & 4.11 & 0.15 & 1.40 & -0.05 \\
\hline Maunjiri × 01/1316 & 3.31 & $0.66^{\star \star *}$ & 1.03 & $0.25^{\star \star \star}$ & 3.68 & $1.81^{* \star *}$ & 1.50 & -0.05 \\
\hline Maunjiri $\times$ Silira & 4.20 & $0.15^{\star}$ & 2.70 & $-0.28^{\star \star \star}$ & 3.33 & -0.42 & 1.32 & $-0.41^{\star \star \star}$ \\
\hline MaunjirixTMS4(2)1425 & 3.76 & $0.15^{\star}$ & 2.79 & $-0.21^{* *}$ & 4.25 & -0.35 & 1.60 & -0.12 \\
\hline LSD (0.05) & 0.25 & & 0.24 & & 1.40 & & 0.38 & \\
\hline $\operatorname{SE}\left(R_{i j}\right)$ & & 0.06 & & 0.06 & & 0.35 & & 0.09 \\
\hline
\end{tabular}

$\mathrm{CGM}=$ cassava green mite, $\mathrm{CMB}=$ cassava mealy bug, $\mathrm{ARN}=$ average root number per plant, $\mathrm{FRW}=$ fresh root weight (kg per plant), $\mathrm{SCA}=$ specific combining ability, $\mathrm{SE}=$ standard error, ${ }^{*} \mathrm{P}<0.05,{ }^{* \star} \mathrm{P}<0.01,{ }^{* \star *} \mathrm{P}<0.001$.

Table 5. Estimates of phenotypic correlation on cassava green mite, cassava mealy bug, average root number per plant and fresh root weight (kg per plant).

\begin{tabular}{lllll}
\hline Traits & CGM & CMB & ARN & FRW \\
\hline CGM & 1 & & & \\
CMB & 0.2 & 1 & & \\
ARN & $-0.25^{*}$ & 0.07 & 1 & \\
FRW & $-0.53^{* * *}$ & 0.02 & $0.42^{* * *}$ & 1 \\
\hline
\end{tabular}

$\mathrm{CGM}=$ cassava green mite, $\mathrm{CMB}=$ cassava mealy bug, $\mathrm{ARN}=$ average root number per plant, $\mathrm{FRW}=$ fresh root weight (kg per plant), ${ }^{*} \mathrm{P}<0.05$; ${ }^{* * *}$ $\mathrm{P}<0.001$.

inheritance of these traits; this view was equally reported by Saleem (2008). For example, Mulola $\times 01 / 1313$ was obtained from (high $\times$ low), TMS4 (2) $1425 \times$ Silira (low $\times$ low), Silira $\times$ Mulola (low $\times$ high), TMS4 (2)1425 $\times$ Maunjiri (low $\times$ average), Mulola $\times 01 / 1316$ (high $\times$ average), parental combinations. Therefore, the performance of hybrids was independent of parent's. These combinations suggest that best progenies might not only be derived from crosses with genotypes having the greatest desirable GCA effects. A similar trend is observed in several previous studies (DaSilva, 2008; Owolade et al., 2008; Mtunda, 2009; Kamau et al., 2010). Significant reciprocal effects for these traits indicated that maternal parents had an effect on the inheritance of these traits. Arunga et al. (2010) reported that significant reciprocal effects would generally dictate the choice of female parent to be included in a breeding programme and that crosses depicting reciprocal effects should not be mixed with direct crosses. Significant reciprocal effects have been reported in cassava (DaSilva, 2008; 
Owolade et al., 2008).

\section{Gene action and relative importance of general and specific combining abilities}

Since general combining ability variances $\left(\delta^{2}\right.$ gca) for all the traits in this study were lower than specific combining ability variances $\left(\delta^{2} s c a\right)$, this means that the SCA was more important in predicting progeny performance for expression of the traits under study. Similar results were reported by DaSilva (2008) and Parkes (2011) in cassava for various traits and concluded that SCA was more important in predicting progeny performance. The prediction ratio $\left[\mathrm{PR}=2 \delta^{2} \mathrm{gca} /\left(2 \delta^{2} \mathrm{gca}+\delta^{2} \mathrm{sca}\right)\right]$ for all the traits was less than 1 , which indicated that non additive gene effects were more predominant in the expression of the studied traits. However, both types of gene effects should be considered when developing breeding schemes for the selection of superior genotypes as suggested from the significance of both GCA and SCA mean squares, and this is consistent with Arunga et al. (2010) recommendation.

The average degree of dominance $\left.\left(\left(\sigma^{2} D / \sigma^{2} A\right)^{1 / 2}\right)\right)$ for all the traits was greater than unit, which indicated the presence of over-dominance in these traits. These findings agree with DaSilva (2008) results, except average root number where partial dominance was reported. Since cassava is highly heterozygous, these results suggest that once an elite clone has been identified and selected, it can be perpetuated through vegetative propagation thereby carrying along the desired trait.

In this study, broad sense heritability ranged from $56.6 \%$ to $57.4 \%$ and narrow sense heritability $(18.0 \%$ to $19.6 \%)$ for all the traits. The high broad sense heritability indicted that all the characters had high genetic variance, that is, additive and non additive variance. Akinwale et al. (2010) reported that high broad sense heritability indicates the presence of large components of heritable portion of variation, which is the portion, exploited by plant breeders. Narrow sense heritability is said to be more important as it measures the relative importance of the additive portion of the genetic variance that can be transmitted to the next generation of the offspring (Fehr, 1991). However, narrow sense heritability was low for all the traits.

According to Falconer and Mackay (1996) lower narrow sense heritability is caused by low additive effects and high dominant gene action, and in this study the over dominance effects have been exhibited. High broad sense heritability has been reported in cassava (DaSilva, 2008; Akinwale et al., 2010; Parkes, 2011). These results therefore, conform to what Kawano et al. (1998) suggested that heritability of cassava after hybridisation is mainly broad-sense in nature as quoted by DaSilva (2008).
Estimates of phenotypic correlation for cassava green mite, cassava mealy bug, average root number per plant and fresh root weight (kilogram per plant)

The positive association between fresh root weight $(\mathrm{kg}$ per plant) and average root number per plant suggested that indirect selection for root weight can be achieved to an extent through selection based on root number and that yield reduction can occur when root number of cassava is reduced. This corroborates with the findings of DaSilva (2008), Akinwale et al. $(2009,2010)$ and Kamau et al. (2010). This also suggests that breeding for any one of these traits will not reduce the desired level of the other and therefore, selection of high yielding genotypes could be based on the number of roots per plant. This in essence agrees with Akinwale et al. (2009) elucidation that traits which are significantly and positively correlated with root yield are crucial towards formulating an efficient cassava breeding program aimed at improving tuberous root yield while negatively correlated characters may result in a reduction in the rate of improvement for some of the characters selected for in a breeding program.

The negative correlation between CGM and fresh root weight (kg per plant) suggests that severe CGM attack results into low root yield. This agrees with several previous studies (IITA, 1990; Bellotti, 2002) of the impact of CGM on cassava root yield. Therefore, losses due to CGM could be greatly reduced by incorporating host plant resistance in cassava improvement scheme. This calls for additional breeding effort and strategies for developing new varieties resistant to CGM to ensure sustainable yields that could ensure future food security in Malawi.

Evidence that both additive and non-additive gene effects are involved in the investigated traits suggests that both types of gene actions should be considered when designing a breeding program since it has significant implications for cassava breeding programs that seek to incorporate resistance to CGM and CMB. In addition, this study suggests that progeny performance may not be based on the parent performance per se, therefore, there is the need to evaluate both parents and their crosses before their use in breeding programme since combining ability analysis based on progeny test data has been found to be useful.

\section{REFERENCES}

Agrobase (2000). Agrobase for Breeders and Agronomists., Winnipeg, Manitoba, Canada: Agronomix Software, Inc.

Akinwale MG, Aladesanwa RD, Akinyele BO, Dixon AGO, Odiyi AC (2010). Inheritance of B-carotene in cassava (Manihot esculenta crantz). Int. J. Genet. Mol. Biol. 2(10):198-201.

Akinwale MG, Akinyele BO, Dixon AGO, Odiyi AC (2009). Genetic variability among cassava genotypes in three agro-ecology zones of Nigeria. Afr. Crop Sci. Conf. Proc. 9:541- 546.

Arunga EM, Van Rheenen HA, Owuoche JO (2010). Diallel analysis of Snap bean (Phaseolus vulgaris I.) varieties for important traits. Afr. J. Agric. Res. 5(15):1951-1957. 
Axtell B, Adams L (1993). Root crop processing. London. International Technology Publicatons Ltd.

Bellotti AC (2002). Arthropod pests. In R.J. Hillocks JM, Thresh AC, Bellotti (Eds.). Cassava: Biology, production and utilization (pp. 209235). London, UK: CABI Publishing.

Bellotti AC, Hershey CH, Vargas O (1987). Recent advances in resistance to insect and mite pests of cassava. In: Hershey, C.H. (ed.) cassava breeding: A multidisciplinary review, proceedings of a workshop held in Philippines, 4-7 March, 1985. CIAT, Cali, Colombia. pp. 117-146.

CIAT (Centro Internacional de Agricultura Tropical) (2004). Project IP3, Improved cassava for the developing world. Annual Report. 2004. Centro International de Agricultura Tropical, Cali, Colombia.

DaSilva AMZ (2008). Breeding potential of cassava (Manihot esculenta Crantz) in Mozambique (PhD Thesis). University of the Free State, South Africa. Retrieved from http://etd.uovs.ac.za/ETD$\mathrm{db} /$ theses/available/etd-09182009081855/unrestricted/DaSilvaAMZ.pdf.

FAO (Food and Agriculture Organization of the United Nations) (1993). Project findings and recommendations. Technical report for project Ref. No. MLW/87/009 on strengthening cassava research and development in Malawi. Rome, Italy: UNDP and FAO.

Falconer DS, Mackay TFC (1996). Introduction to quantitative genetics, $4^{\text {th }}$ ed., England. UK Longman Group Ltd. P. 464.

Fehr WR (1991). Principles of cultivar development (vol. 1): Theory and Technique. lowa, USA: Macmillian Publishing Company. P. 536.

Githunguri CM (1991). Cassava processing and utilization in Kenya. The role of root crops in regional food security and sustainable agriculture. In Proceedings of $4^{\text {th }}$ Eastern and Southern Africa region workshop on Root and tuber crops (pp. 11-16). Ibadan, Nigeria: IITA.

Hahn SK (1988). Overview of traditional processing and utilization in Africa. In Proceedings of workshop on the potential utilization of cassava as livestock feed in Africa, Ibadan, Nigeria. http://www.fao.org/wairdocs/ILRI/x5458E/x5458e05.htm.

Lebot V (2009). Tropical Root and Tuber Crops, cassava, sweet potato, yams and aroids. London, UK: CABI. P. 413.
IITA (International Institute of Tropical Agriculture) (1990). Cassava in Tropical Africa. A Reference Manual. London, UK: Chayce Publication Services. P. 176.

Kamau J, Melis R, Laing M, Derera J, Shanahan P, Ngugi E (2010). Combining the yield ability and secondary traits of selected cassava genotypes in the semi-arid areas of Eastern Kenya. J. Plant Breeding Crop Sci. 2 (7):181-191.

Moyo CC, Benesi IRM, Sandifolo VS (1998). Current status of cassava and sweet potato production utilization in Malawi. Lilongwe, Malawi: Department of Agricultural Research and Technical Services

Mtunda KJ (2009). Breeding, evaluation and selection of Cassava for high starch content and yield in Tanzania (PhD Thesis). University of KwaZulu-Natal, Pietermaritzburg, South Africa. http://www.hdl.handle.net/10413/611:222.

Nweke FI, Spenser DSC, Lynam JK (2002). The cassava transformation. New York, USA: Michigan State University.

Opeke RO (1991). Root and tuber crops in Southern Africa: Which way to go? The role of root crops in regional food security and sustainable agriculture. In Proceedings of fourth Eastern and Southern Africa Region Workshop on root and tuber crops (pp. 1-4). Ibadan, Nigeria: IITA

Owolade OF, Dixon AGO, Alabi BS, Akande SR, Olakojo SA (2008). A combining ability analysis of cassava (Manihot esculenta Crantz) genotypes to anthracnose disease. Electronic J. Environ. Agric. Food Che. 7(6):2959-2968

Parkes EY (2011). Assessment of genetic diversity, combining ability, stability and farmer preference of cassava germplasm in Ghana (PhD Thesis). University of the Free State, South Africa.

Saleem MY (2008). Genetic analysis of Basmati Rice (Oryza sativa L.) (PhD Thesis). Institute of Pure and Applied Biology, Bahauddin Zakariya University, Multan, Pakistan. p. 160.

Silvestre P (1989). Cassava. London, UK: Macmillan Publishers Ltd. P. 82. 